\title{
Sleep disorders frequency in post-polio syndrome patients caused by periodic limb movements
}

\author{
Maria Auxiliadora de Paiva Araujo', Tatiana Mesquita e Silva², \\ Gustavo Antonio Moreira33, Márcia Pradella-Hallinan³, \\ Sergio Tufik ${ }^{4}$, Acary Souza Bulle Oliveira ${ }^{4}$
}

\begin{abstract}
Post-polio syndrome (PPS) in individuals with polio longer than 15 years is characterized by weakness and/or muscle fatigue, deficit of deglutition and breath and periodic limb movements (PLM) during sleep. We undertook a review of 99 patients with PPS, and assessed the frequency of PLM through polysomnographic recordings at our sleep disorders unit. The total number of PLM, total time of sleep (TTS), efficiency of sleep (EfS), awaking index (Al) and apnea-hypopnea index (AHI) were analyzed. Sixteen patients presented PLM in excess of 5 for the entire night. When comparing these with the group without PLM, a correlation was found ( $p=0.001$ ). Significant difference was found for the correlation of the parameters: IAH, ID, TTS and EfS when compared the two groups. There is a close relationship between PPS and PLM.
\end{abstract}

Key words: post-polio syndrome, periodic limb movements, sleep disorder, polysomnography.

Frequência de transtornos do sono em pacientes com síndrome pós-pólio causados por movimentos periódicos dos membros

\section{RESUMO}

A síndrome pós-pólio (SPP) se manifesta em indivíduos que tiveram poliomielite, após 15 anos ou mais. Caracteriza-se por fraqueza e/ou fadiga muscular, déficit de deglutição e respiração e movimentos periódicos dos membros (PLM) no sono. Identificou-se a freqüência de PLM no sono em 99 polissonografias de pacientes com SPP, atendidos no ambulatório da Universidade Federal de São Paulo/ Escola Paulista de Medicina. Analisouse número total de PLM, tempo total de sono (TTS), eficiência do sono (EfS), índice de despertar (ID) e índice de apnéia-hipopnéia (IAH). Dezesseis pacientes apresentaram n ${ }^{\circ}$ de PLM maior que 5 para a noite inteira. Não foi encontrada diferença significativa para a correlação dos parâmetros: índice de apnéia e hipopnéia, índice de despertar, tempo total de sono e eficiência do sono quando comparados os dois grupos. Portanto, considera-se a existência de uma relação entre a presença de PLM e a SPP.

Palavras-chave: síndrome pós-poliomielite, movimentos periódicos dos membros, distúrbios do sono, polissonografia.

Correspondence

Tatiana Mesquita e Silva Av. Rebouças 1278 / 1002 05402-000 São Paulo SP - Brasil E-mail: tatimsilva@gmail.com

Received 6 May 2009 Received in final form 20 August 2009 Accepted 31 September 2009
Poliomyelitis is not just an anterior horn disease of the marrow, but is also a diffuse neuronal illness usually involving reticular formation in the cerebral trunk. Inside regions of the nervous system of patients with polio have significant neuronal destruction not only in the anterior horn motor neurons of the marrow, but also in sensorial areas like the posterior horn and the ganglia of the dorsal root, as well as prefrontal cortex area, hypothalamus, thalamus, nucleus and cerebellum, several cranial nerves nucleus, reticular formation and cerebral trunk ${ }^{1}$. Post-polio syn- 
drome (PPS) is a nervous system disorder that appears in individuals with polio, after 15 years or more on average, with a new symptoms like: gradual muscular weakness, fatigue, muscular and joint pains, showing a reduction of the functional capacity and/or developing new incapacities. Some patients also develop deglutition and breath difficulty, anxiety and sleep disorders like periodic limb movements (PLM) ${ }^{2}$. A number of hypotheses for the cause of the PPS can be found, however the most accepted is that PPS is not caused by a new poliovirus activity, but due to extreme use of the motor neurons over many years. The virus can damage up to $95 \%$ of the anterior horn motor neurons of the marrow, killing at least 50\% of them. With the death of these neurons, muscles stay without their enervation, provoking paralysis and atrophy. Although damaged, the remaining neurons send ramifications to activate these orphans muscles recovering the neuromuscular function partially or totally depending on the number of involved neurons in the "adoption". One neuron can launch derivations to connect from 5 to 10 times more neurons than originally. Thus, a neuron innerves a bigger number of neuromuscular fibers than it is usual to, reestablishing the motor function; however, overloaded, after many years of functional stability, new pathological symptoms arise ${ }^{1}$. In 2001 the diagnostic criteria for PPS were brought up to date at the International Conference of the PPS ${ }^{3}$. Periodic limb movements in sleep (PLMS) are highlighted through polysomnography as a repetitive episode of muscular contractions with duration of 0.5 up to 5 seconds, separate for a typical interval from 4 to 90 seconds. The occurrence of PLMS in frequency of 5 or more per sleep hour is considered as abnormal and its association with insomnia or daily sleepiness suggests the diagnosis of PLMS disorder. The patient, however, can be asymptomatic with the movements verified by an observer or incidentally found during polysomnography ${ }^{4-12}$.

Polysomnography is conducted during sleep with sensors delicately placed on the skin with a tape. It allows for checking some physiological parameters such as: EEG brain activity, the eye movement, limb movements and the submental muscle, breath, heartbeat and blood gases $\left(\mathrm{O}_{2}\right.$ and $\left.\mathrm{CO}_{2}\right)$. The sensors send information to computer devices to collect data and to facilitate real time sleep

Table. Demographic data of patients.

\begin{tabular}{lcccc}
\hline $\begin{array}{l}\text { Population } \\
\text { analysis }\end{array}$ & Individuals & $\begin{array}{c}\text { Age } \\
\text { average }\end{array}$ & $\begin{array}{c}\text { Standard } \\
\text { deviation }\end{array}$ & $\%$ \\
\hline $\begin{array}{l}\text { Gender } \\
\text { Male }\end{array}$ & 39 & 44.9 & 10.46 & 39.4 \\
Female & 60 & 47 & 9.77 & 60.6 \\
Total & 99 & 46.2 & 10.04 & 100 \\
\hline
\end{tabular}

analysis. The whole process is painless and allows a normal sleeps ${ }^{5}$. The polysomnography sleep study remains a standard in order to establish PLM diagnosis ${ }^{12-14}$.

The objectives were to identify the frequency of periodic limb movements during sleep in patients with postpolio syndrome, and compare sleep quality variables, check the difference on AHI, and verify if polysomnography helps to confirm sleep disorders in PPS patients with and without PLM.

\section{METHOD}

This study was descriptive retrospective; 199 polysomnography recordings from January 2003 to December 2006 were reviewed; 34 were excluded from patients with polio sequels and 165 were selected with confirmed diagnosis post-polio syndrome. The individuals had polio paralysis in the past; having partial motor recovery at least 15 years; presence of abnormal muscular fatigue. Ninety nine patients were randomized selected according to PPS International Conference diagnostic criteria, assisted at UNIFESP/EPM clinic. The demographic data of the patients are showed in Table. Total PLM number $\left(\mathrm{PLM} \mathrm{n}^{\circ}\right)$, total sleep time (TST), sleep efficiency (SE), awakening index (AI), apnea hypopnea index (AHI) were studied. The statistical analysis was made with Statistica software (Version 5.1 - Statsoft, Inc, Tulsa, OK) and Microsoft Excel (2003 SP2, Portland, OK) for data analysis and graph plotting. Descriptive statistic was used. Komogorov-Smirnov test (K-S) proved the real data adjustment by normal distribution. Non-paired t-test was used to compare the

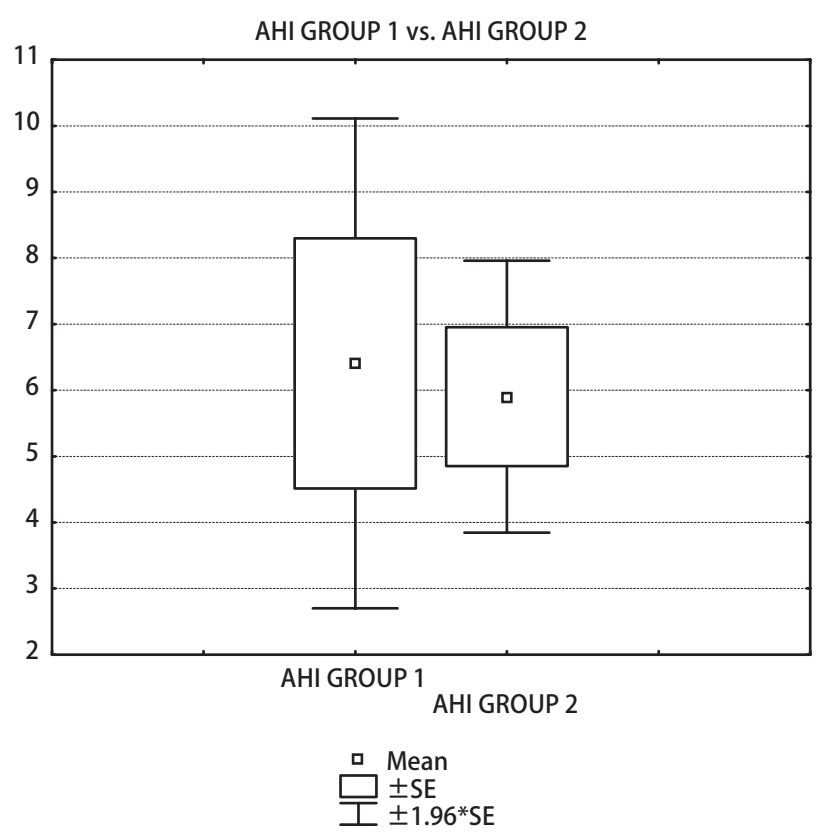

Fig 1. The average and average standard deviation of $\mathrm{AHI}$ in groups with / without PLM ( $p=0.87)$. 
polysomnography variables of sleep quality with PLM $>5 / h$ index with the sleep quality polysomnography findings from non PLM individuals (PLM $<5 / h$ index). The statistical tests where significant for $5 \%(\mathrm{p} \leq 0.05)$ alpha error.

\section{RESULTS}

Sixteen patients (16.6\%) showed an PLM index higher than 5 for the whole night, which is pathological.

No significant differences were found for the following correlation parameters: apnea-hypopnea index, awakening index, total sleep time and sleep efficiency when compared both groups.

The AHI value achieved comparing patients with and without PLM was $\mathrm{p}=0.87$ (Fig 1 ). To AI, the value was $\mathrm{p}=0.93$, to TST the value was $\mathrm{p}=0.54$ (Fig 2$)$, and to the SE the p value was 0.54 .

\section{DISCUSSION}

We found $16.6 \%$ of the polysomnographies with PLM index $>5$ per hour in post polio patients; this is in accordance with Bruno's ${ }^{14}$ study where PPS patients referred sleep disorder by involuntary muscle contraction. This suggests that PLMS is related to the physiopathology of PPS.

The frequency of PLMS and PPS frequency are not well known. The PLMS are related to the awakening number, sleep fragment architecture and sleep-vigil cycle increase.

Sometimes the PLMS are found in PSG recordings in patients complaining of insomnia or daily somnolence. PLMS frequency or severity determine the complaint of sleep but remain undetermined, Pennestri et al. ${ }^{15}$, note

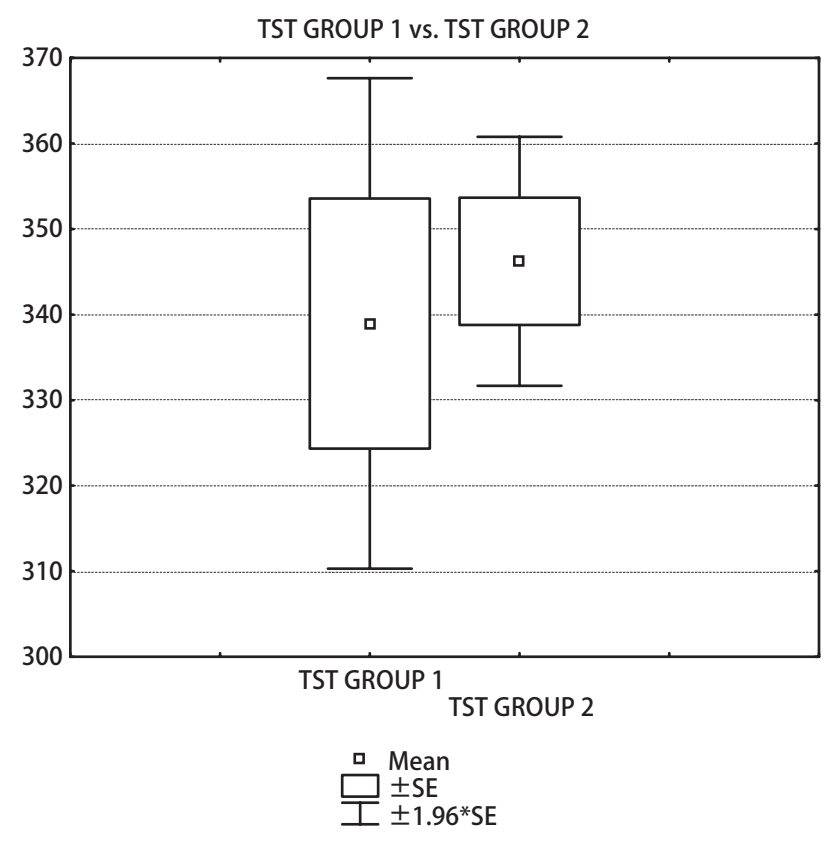

Fig 2. Showing the average and standard deviation on the total sleep time in groups with / without PLM ( $p=054)$. that for healthy individuals, with similar age of this study, PLM average ranges from 10 to 12 . PLMS remains a causal factor of bad sleep quality through micro arousals ${ }^{11}$.

One interesting finding in this study was that PLMS was unknown to patients during a clinical interview, since the excitation associated to the PLMS did not result in a full sleep awakening, which is in accordance with Sforza's $^{15}$ findings. Patients with several awakening episodes highlight the following factors: obstructive sleep apnea, snoring, periodic limb movements, pain and cramp ${ }^{15}$. No statistical significance was found when was compared the AHI on both groups, showing that the real prevalence of PPS in patients with or without PLMS and its combination with apnea-hypopnea is not clearly determined, concurring with Jubelt et al. ${ }^{16}$.

Both groups present apnea-hypopnea index higher than 5 episodes per hour and show a reduction in sleep quality associated to PLM. PLM does not affect AHI. A high average awakening index impairs sleep. An AHI higher than 5, together with PPS, drives this high average, and is not worsened by PLM. PLM does not change the AI. There was a non significant impairment by PLM with total sleep time reduction in both groups (bigger than 300 minutes or 5 hours) while the ideal is higher than 420 minutes or 7 hours. There is a reduction higher than 10 minutes within the groups which is considered to be irrelevant; this suggests that AHI and PPS could lead to this change and not PLM per se. TST is reduced in PLM. Although there was no increase in AI, the awakening time increased in patients.

Good SE is considered to be higher than $85 \%$. The patients had a SE mean of 71-73\%, suggesting that AHI plus PPS let SE lower and not the PLM. The SE is reduced in the PLM group due to the increase awakening time TST is decreased taking to an inefficient sleep however significantly reduced.

Many PPS patients relate sleep quality reduction referring to excessive daytime somnolence, weariness, headache and fatigue, but in this study no statistical significance was found in the following variables: apnea-hypopnea index, sleep efficiency, awaking index and total sleep time in both groups. Several authors find clear changes in the sleep architecture caused exactly by a lack of sleep quality. This suggests that PPS or AHI or both could be the harmful factors to sleep but not to PLM.

Bruno's ${ }^{14}$ study was the first to propose the apparent increase of ASM (abnormal sleep movements) on survival patients of polio with daily fatigue which is a common feature of PPS. He assessed ASM related to possible sleep architecture perturbation in the attempt to propose an effective treatment. It is important to remove sleep perturbations caused by fatigue and to verify sleep history of patients with post polio, asking not only about sleep apnea 
symptoms - which frequently occur in polio survivors but also about ASM. Partners of patients should also be asked about ASM because most of the polio survivors are unknown that they have $\mathrm{AMS}^{14}$.

PSG recordings were effective in terms of diagnosis alterations. PLMS are rhythmic contractions, repetitive and stereotyped of extremity muscles in sleep. They produce superficial electroencephalograph traces in polysomnographic records with possible sleep-vigil cycles and awakening episodes ${ }^{16}$. This suggests that sleep disturbances are more prevalent in PPS possible due to PLMS or AHI provoking frequent awakenings during the night. A further article to explore this aspect should look at PPS in patients without apnea.

The clinical history is still vital but polysomnographic studies are a good reason to avoid diagnostic misinterpretations. It is important take in account that the PSG findings themselves do not determine the illness, but should be considered their as part of clinical context ${ }^{17}$. PLMS may be associated with dopaminergic system deregulation or hypoactivity due to excessive diurnal sleepiness causing functional impairment and a lost of sleep quality ${ }^{18}$.

In conclusion, the polysomnography records are an apt way of establishing PLMS in PPS. Understanding the role this plays in the lives of PPS will allow health carers to work on enhancing the overall sleep quality of polio survivors.

\section{REFERENCES}

1. Quadros AAJ. Síndrome pós-poliomielite (PPS): uma nova doença velha. Tese de Mestrado, Universidade Federal de São Paulo - Escola Paulista de Medicina. São Paulo, 2006.

2. Oliveira ASB, Quadros AAJ, Conde MTRP. Documento técnico da síndrome pós-poliomielite. UNIFESP/EPM. São Paulo: Associação Brasileira de Síndrome
Pós-poliomielite [atualizado em junho 2004]. Disponível em http://abraPPS. trenche.com.br/wp-content/uploads/2007/02/doc_tec_PPS-1.pdf

3. March of Dimes. Post-polio syndrome. Identifying best practices in diagnosis \& care. White Plains, NY: March of Dimes Fundation, 2001.

4. Haba-Rubio J, Ibanez V, Sforza E. An alternative measure of sleep fragmentation in clinical practice: the sleep fragmentation index. Sleep Med 2004;5: 577-581.

5. Garcia-Jiménez MA. Trastornos del movimiento y actividad motora en sueño. Rev Neurol 2001; 32: 574-580.

6. Kandel ER, Schwartz JH, Thomas MJ. Princípios da neurociência. $4^{a}$ Ed. São Paulo: Manole, 2002

7. Rama AN, Kushida CA. Restless legs syndrome and periodic limb movement disorder. Med Clin N Am 2004;88:653-667.

8. Sforza $E$, Jouny $C$, Ibanez $V$. Time course of arousal response during periodic leg movements in patients with periodic leg movements and restless legs syndrome. Clin Neurophysiol 2003;114:1116-1124.

9. Vetrugno R, Angele RD, Montagna P. Periodic limb movements in sleep and periodic limb movement disorder. Neurol Sci 2007; 28(Suppl): S9-S14.

10. Haba-Rubio J, Sforza E. Night-to-night variability in periodic leg movements in patients with restless legs syndrome. Sleep Med 2005;6:259-267.

11. Sforza $E$, Johannes M, Claudio B. The PAM-RL ambulatory device for detection of periodic leg movements: a validation study. Sleep Med 2005;6:407-413.

12. Bastuji H, Garcia-Larrea L. Sleep/wake abnormalities in patients with periodic leg movements during sleep: factor analysis on data from 24-h ambulatory polysomnography. J Sleep Res 1999;8:217-223.

13. Rye DB. The two faces of eve dopamine's modulation of wakefulness and sleep. Neurology 2004;63(Suppl 3):S2-S7.

14. Bruno RL. Abnormal movements in sleep as a post-polio sequelae. Am J Phys Med Rehabil 1998;77:339-343.

15. Pennestri MH, Whitton S, Adam B, Petit D, Carrier J, Montplaisir J. PLMS and PLMW in healthy subjects as a function of age: prevalence and interval distribution. Sleep 2006;29:1183-1187.

16. Jubelt B, Drucker J. Poliomyelitis and the post-polio syndrome. Reimpresso por Motor Disorders, In: Younger DS (Ed). Lippincott Williams \& Wilkins, Philadelphia, 1999. Disponível em http://www.ott.zynet.co.uk/polio/lincolnshire/ library/jubelt/polioandthepps.html

17. Pastor J, Fernández-Lorente J, Ortega B, Galán JM. Análisis comparativo de la história clinica y la polisomnografía en la patología del sueño. Relevancia diagnóstica de la polisomnografia. Rev Neurol 2001;32:22-29.

18. Rodrigues RND, Abreu e Silva AAA. Sonolência diurna excessiva pós-traumatismo de crânio: associaçao com movimentos periódicos de pernas e distúrbio de comportamento do sono REM. relato de caso. Arq Neuropsiquiatr 2002;60:656-660. 